ests, political leadership, bureaucratic politics, administration of small communities, LDC development policy, and international trade policy.

Political scientists are now being invited to take a larger role in this interdisciplinary community, in part because it has been increasingly recognized that politics, rather than economics, is triumphant in. fields such as agricultural trade and technology development; and it has also become obvious that political leadership is of crucial importance for regional and community development.

Traditionally, agricultural issues were studied by "rural" social scientists within the colleges of agriculture (mainly agricultural economists and rural sociologists) and home economics. These "rural" or "agricultural" social scientists created strong disciplinary subfields which in time made major contributions to theory, to methodology, and to problem-solving. Today social scientists expect to have expanding roles in agricultural and rural development, but they are in turn obliged to look beyond the traditional subfields for an understanding of the dynamic rural environment.

The effort to expand the research community and its research agenda has been nurtured through interdisciplinary conferences, foundation funding, joint publications, new journals, and now by specific efforts to create an omnibus "agricultural agenda." For example, an Agriculture and Humanities project organized by philosopher Richard Haynes at the University of Florida repeatedly brought together social scientists, humanists, and natural scientists on numerous occasions, culminating in the creation of a journal, Agriculture and Human Values. Also, the Social Science Agricultural Agenda Project (SSAP), sponsored by major foundations and by the U.S. Department of Agriculture, is currently organizing an interdisciplinary agenda. SSAP and other committees are moving strategically to open new financial support for rural social science.

One result of these initiatives has been to build participation from among "nontraditional" rural scholars particularly in the disciplines of philosophy, political science, history, and geography. These "nontraditional" scholars may find appreciative audiences for their works, and outlets in authored and edited books, and in scholarly journals, the articles in which are reported in the Social Science Citations Index. Finally, there is the prospect both for small grants for individual research and also for public funding of large grants for group and interdisciplinary research and symposia. Further inquiry my be made to Don Hadwiger, Department of Political Science, lowa State University, Ames, IA 50011; phone (5I5) 294-4144.

\section{The Advisory Committee on Historical Diplomatic Documentation}

\author{
Bradford Perkins
}

University of Michigan

The Advisory Committee on Historical Diplomatic Documentation met in Washington on January 7 and 8, 1988. The Committee considered the implementation of President Reagan's so-called "1960 by 1990" order of November 1985, and broader questions about the future of the Foreign Relations (FRUS) series and the perennial problems of declassification.

\section{"1960 by 1990"}

Last year the Committee expressed concern that President Reagan's directive that all FRUS volumes covering the years down to 1960 be published by 1990 might not be fulfilled; this year it is even more deeply concerned. The schedule established in 1986 to fulfill the President's order called for publication of nine FRUS volumes in 1987. In fact, although nine (including a two-part publication delayed from 1986) were actually published in 1987, five volumes planned for publication did not appear; two of them are still held up at the declassification stage. The shortfall experienced in 1987 is certain to be compounded in 1988, when, according to the schedule laid down in 1986, thirteen volumes are to appear. The President's objective will not be achieved. 
For this, the Historical Office, which has proceeded with efficiency and dispatch, cannot be blamed. It has compiled most of the volumes covering the 1958-1960 triennium and is well along with the remainder. Nor do publication costs excuse the short-fall; imaginative strategies developed by the Historian have at least temporarily reduced problems in this area.

The critical problem is slowness in the declassification process. Thirteen volumes cleared by the State Department's Classification/Declassification Center, after consultation with appropriate agencies in the Department and elsewhere, await final clearance by the National Security Council. Declassifiers at the NSC have been diverted this year by demands for materials relating to the Iran/Contra affair. However, the Committee members doubt that, when these demands end, NSC declassifiers can complete their task, which involves approximately thirty volumes, in time to meet the 1990 deadline. Nor has the CDC kept to the schedule laid down in 1986. Much of the tardiness can be explained by severe budgetary reductions CDC has experienced. However, CDC's record this year and in previous years suggests that, even when funds for reviewers are available, it proceeds at a pace much slower than that foreseen when the present program was established. Perhaps equally important, CDC does not arrange its schedule so that the volumes most likely to create difficulties are reviewed first.

In sum, it is likely that the President's "1960 by 1990" goal will not be met, certainly not unless major efforts are made to put the program on track. Indeed, it is not impossible that publication of FRUS volumes will soon fall farther behind.

To look ahead, the prospects for the series after 1990, when volumes for the 1960s should begin to appear, look grim. Here too declassification problems figure as a major obstacle. In addition, neither the Kennedy nor the Johnson Library has sufficient archival personnel to keep up with the needs of the Historical Office. Already, work on the Department's valuable series on Vietnam, running ahead of FRUS coverage, has had to be suspended, and volumes on other topics face a serious threat.

\section{The Future of the Foreign Relations Series}

For many years, FRUS has been a publication of record, providing documents necessary to an understanding of the history of U.S. foreign policy. The expanded American role in the world has made this aim more difficult to achieve, as have the involvement of agencies other than the Department of State and the ever-growing volume of records. To these latter factors, which continue to increase in importance, have recently been added budgetary constraints, constraints which seem certain not to ease. Although increasing use of microfiche publication may ease the pressure, FRUS will almost certainly include a smaller proportion of the available records than it has in the past.

Change is certain; how it is to be managed is not. What principles should guide the Historical Office? What is the minimum number of volumes necessary to do justice to the record? How helpful can microfiche be? If the size of the series is reduced, should compilers present reasonably complete documentation on important issues (provide a rounded story) and scant others? Should they omit nothing, at least to the extent of directing scholars to appropriate sources (provide a geography of the archives)? What might be an appropriate compromise?

\section{Declassification}

The committee has long felt that it does not receive enough information to enable it to assure the associations it represents that FRUS publishes as faithful a record as is possible, given legitimate security concerns. Efforts to establish a sustained dialogue with the Department have so far met with limited success; nor has the Department developed its own position.

Dwight R. Ambach, Acting Director of the Office of Systematic Review, and several of his colleagues from CDC discussed in some detail deletions made in three FRUS volumes recently cleared. No similarly detailed discussion has previously been held. Although the volumes discussed were, in the words of one of the CDC representatives, "not problem vol- 
umes," the committee learned a great deal about the general criteria used by CDC.

\section{The Committee, the Office of the Historian, and the Department}

The committee received helpful assistance from the Historian and his staff, the support of George B. High, Deputy Assistant Secretary for Public Affairs, and exchanged views with Charles E. Redman, Assistant Secretary for Public Affairs.

Present during the meeting were Robert Dallek, representing the American Historical Association; Deborah Larson, representing the American Political Science Association; John Hargrove, representing the American Society of International Law; Bradford Perkins, committee chair, representing the Organization of American Historians; and Warren I. Cohen and Michael $H$. Hunt, representing the Society for Historians of American Foreign Relations. (Blanche Weisen Cook, representative of the American Historical Association, and Michel Oksenberg, representative of the American Political Science Association, were unable to attend.

\section{Applied Career Options for Political Scientists}

Curriculum planners, career counselors and individual jobseekers may still have difficulty conceiving of the range of career opportunities available to political science students. The APSA publications, Careers and the Study of Political Science and Alternative Careers for Political Science identify careers in law, government, interest groups and associations, research and consulting, international organizations, business, journalism, and teaching.

An APSA survey of political scientists working in nonacademic settings in the early 1980s greatly expanded understanding of the scope of applied careers. The following is a list of the functions or job titles identified in the survey.
Investment Officer

Program Evaluator

Director, Division of Policy Studies

Public Affairs Research Analyst

Deputy Secretary for Administration,

State Departments of Welfare

Plans and Review Officer, USIA

Assistant Deputy Secretary to Governor

Private Foundation Program Director

International Research Specialist

Senior Editor

Principal Secretary to Prime Minister

State Department, Director, Policy and Coordination

Associate Research Director, Advertising Firm

City Housing Manager

Advisor to Chairman of State Energy

Commission

Attorney

Corporate Senior Advisor for Governmental Relations

Librarian

Federal Commission Senior Policy Analyst

State Department Officer

Director of Political Information Products

Campaign Finance Analyst

City Project Coordinator

Executive Director, Special Interest

Association

Consultant

County Clerk

Senior Advisor, Department of Treasury

Investigator, OPM

Vice President, Market Research

Director, Public Affairs

Corporate Economist

Research Supervisor

Manager of Political Programs

Chief of Staff, Committee, U.S. House of Representatives

U.S. Senate Office, Legislative Director

Director, County Economic Development Office

U.S. House of Representatives,

Administrative Assistant

Principal Program Evaluator

Political Commentator

Director of Regulatory Compliance

journalist

President, Research Consulting Firm

Director, Intelligence Operations

Press Officer, U.S. Embassy

Executive Secretary of the Board of Selectmen

Political Officer, U.S. Embassy

USIA, Special Advisor to the Administrator

Governor's Office, Director of State

Operations

U.S. Congress, Staff Assistant

County Treasurer

Vice President, Governmental Affairs,

Engineering Firm

Supervisor, State Office of Contract 